\title{
Self-concept in the Formation of Educators of Indigenous Areas in Mexico
}

\author{
Luis Fernando Hernández Jácquez \\ Pedagogical University of Durango, Mexico \\ E-mail: 1fhj1@hotmail.com
}

Received: Nov. 20, 2016 Accepted: Jan. 13, 2017 Published: February 1, 2017

doi:10.5296/jse.v7i1.10639 URL: http://dx.doi.org/10.5296/jse.v7i1.10639

\begin{abstract}
The presented study talks about self-concept in student-educators who are academically prepared in a bachelor degree in pre-school and elementary school education when it comes to indigenous areas in Mexico. According to the very students there is a lower perception of them when comparing to their colleagues in urban areas. By taking into account and considering the reference of the multidimensional model of self-concept by Shavelson, Hubner and Stanton (1976), as well as the research questions: What is the level of self-concept of student-educators of the LEPEPMI? And, what is the relation between the level of self-concept and several social, academic and professional variables of the student-educators of the LEPEPMI? A quantitative non-experimental and cross-sectional study was conducted with 155 participants, having found as most significant results that the subjects demonstrated a low level of global self-concept. Furthermore, this concept was statistically related only with the semester of study for the student-educators.
\end{abstract}

Keywords: Self-concept, student, educator, indigenous area, elementary school. 


\section{Introduction}

According to Purkey (1970) self-concept is a "complex and dynamic system of beliefs that an individual considers as true facts about him/herself, giving each belief a corresponding value", and considering the relevance of that such a theoretical concept has acquired in the past years when it comes to the educational thematic, it is the reason for the link with different variables.

As a proof of the discussed above, the study conducted by Ramos, Rodriguez, Fernandez, Revuelta and Zuzagoita (2016) is considered due to the fact that their research was associated to the social support perceived. Bartra, Guerra and Carranza (2016) linked their study to depression, while Revuelta, Rodriguez, Ruiz and Ramos (2015) related theirs to the academic performance of students in mandatory secondary school in Spain.

In the Mexican context, Ibarra and Jacobo (2016) described the evolution of academic self-conceptduring adolescence. Hernandez (2016) analyzed self-concept in Mexican scholar children. Additionally, Barraza and Hernandez (2016) found a positive relation between self-concept and academic performance of middle school students.

Valdez, Sanchez and Carlos (2012) investigated whether the variables, such as the scholar regularity and social self-concept differentiate a group of students who presented bullying behavior towards schoolmates from those who do not present such conducts, finding the conclusion that the group with a higher level of violent behavior differs from those who have a lower level due to a greater history of behavioral problems and a self-concept rather negative.

On the other hand, Garcia (2005) studied the dimensions of self-concept in regard to self-esteem and to the academic performance of 315 students, having found that self-esteem presented a greater correlation with physical self-concept than with academic performance. The higher dimensions of self-concept (based on Harter's scale of self-perception profile) were friendship and self-esteem.

Additionally, Valdez and Gonzalez (1999) investigated the differences of self-concept between men and women in a sample of 600 individuals, having found that in general terms women consider themselves more romantic, attentive, affectionate, sensitive and fault-finder, while men perceive themselves more active, dishonest, stubborn, aggressive, humorist, intelligent and disobedient than women.

When it comes to the study of self-concept in Mexican teachers Martinez (2003) found in a selected sample of educators a positive self-concept of themselves by stating that the self-perception shown in these individuals is reflected in the different analyzed dimensions. Professional, social, emotional, family and physical, while Ibarra, Armenta and Jacobo (2014) studied the existing links between self-concept, coping strategies and teaching development of the educators who work in two different contexts: An island and the highlands, reaching the conclusion that those professors who work in an island demonstrated an academic and social self-concept higher than the ones who work in the highlands; nevertheless, emotional, 
family, and physical self-concept presented in the educators from the highlands was above the one presented in their counterparts working in an island.

Thus, the research objective of this investigation is narrowed to determine the level of self-concept in the students of the Bachelor program in Pre-school and Elementary Education for Indigenous Areas (LEPEPMI program looks for professionalizing the teachers in service from basic education level in indigenous communities of the region). These educators attend a Mexican university, which brings the situation of having to work with these teachers in service in a classroom and the unequal perception of themselves when comparing to their counterparts who work in urban areas. This issue was originally expressed by them as a probable effect resulting from working in a different context, which includes: labor conditions, prospects, professional development and the access to different tools and materials among others.

Therefore, the research questions for this study are:

1. What is the level of self-concept in student-educators of the LEPEPMI?

2. What is relation between the level of self-concept and certain social, academic and professional variables of the student-educators of the LEPEPMI?

\section{The Shavelson, Hubner and Stanton self-concept model as a theoretical framework}

The general theoretical framework of the study is proven by the Shavelson, Hubner and Stanton model (1976) who based on the definition by Purkey (1970) explain that self-concept is a complex, organized, and dynamic system of learned beliefs, attitudes and opinions that each person holds to be true about his or her personal existence, as well as, the perceptions made throughout the interpretation of own experience and environment. These, are also influenced in a special manner by the reinforcement and feedback from our loved ones, as much as our own cognitive mechanisms.

In that respect, Shavelson et al. (1976) provided a multidimensional and hierarchical model of self-concept, understanding this with seven fundamental characteristics: organized and structural, multifaceted, hierarchical, stable, evolutionary and dynamic, evaluative and differentiable. Global Self-concept is structurally divided into non-academic and academic, including within the first one the social, emotional and physical dimensions, while in the second one, the dimensions regarding study curricula. These dimensions are described below.

o Social dimension (social self-concept). It refers to the perception that an individual has about happiness and the difficulty to have relationships with others. This dimension includes family self-concept, which is the perception that each person holds in his or her family, the relationship with parents, siblings and the emotions regarding this context.

o Emotional dimension (emotional self-concept). It is concerning self-control of emotional states of a person and their responses in specific situations.

o Physical dimension (physical self-concept). This is the perception that a person holds about their physical appearance and condition. 
o Academic dimension (academic self-concept) It refers to the perception that a person holds about the quality of their performance as student. Such a dimension involves teachers and appreciated qualities as students.

Shavelson et al. (1976) pointed that self-concept is not the only entity that a person has, nor the most important, yet this hypothetical construct has a potential of usefulness in the explanation and prediction of the conduct in individuals. This self-perceptions influence as much in conduct as this one does in the very self-perceptions (Marsh, 2005, quoted by Veliz\& Apodaca, 2012). In this model it is considered that self-concept is evolutionary and dynamic. It is not determined once for all, which provides the opportunity to intervene with strategies to configure self-concept positively in students.

\section{Methodology}

This study is framed in the quantitative approach of investigation, it is a correlational research and non-experimental, this is because... "The scientist does not have a direct control on independent variable because their manifestations have already occurred or because they are inherently not manipulable" (Kerlinger \& Lee, 2002, p. 504); and cross-sectional or transversal because data will have been collected in five stages (Hernandez, Fernandez \&Baptista, 2010), corresponding to the second semester of the year 2016.

\subsection{Hypothesis}

Considering the situation to investigate, the research questions, previously defined, and the theoretical base, already addressed, the following hypothesis is presented:

$\mathrm{H}_{\mathrm{i} 1}$ : The level of self-concept of the student-educators of the LEPEPMI is low.

$\mathrm{H}_{\mathrm{i} 2}$ : There are certain social, academic and professional variables which have a relation with the level of self-concept of the student-educators of the LEPEPMI.

\subsection{Participants}

The total amount of student-educators who participated in the study is 155 taking into account the following characteristics:

o $44.3 \%$ of the participants are male and $55.7 \%$ are female.

o Age between 26 and 78 years old.

o Marital status: $51.7 \%$ single and $48.3 \%$ married.

o Range of years working as educators: 1 to 33 years, within the participants $81.3 \%$ have been working as educators between 1 and 4 years.

o Level of education in which they work: $24.5 \%$ in pre-school, $57.3 \%$ in elementary school and $18.2 \%$ in middle school.

o School program in which they work: $29.9 \%$ work in school of independent grades organization and $70.1 \%$ work in multiple graders in the same group. 
o When it comes to the semester the participants are attending: $29.1 \%$ attends the first semester, $11.3 \%$ attend the second, $22.5 \%$ attend the third, $7.9 \%$ attend fifth semester, $2.6 \%$ attend sixth, and 26.5\% attend the seventh semester. By the time this study was conducted there were no students attending fourth semester due to certain institutional conditions.

\subsection{Technique and instrument}

The technique for the date collection was a survey, and the self-administered tool was a questionnaire of self-concept Form 5 (AF5, Garcia \&Musito, 2001) which according to Sallum, Marin and Reyes (2011) provides a reliability of .88 in Cronbach's Alpha. It measures self-concept through academic, social, emotional, family and physical dimensions. It is well-founded in the multidimensional theoretical model by Shavelson at al. (1976). The sum of this dimension is the corresponding level of global self-concept. The questionnaire was answered through a Likert scale of 5 items: always, almost always, sometimes, hardly ever, never, with the values of 5 to 1 respectively.

It was added to the questionnaire a background where data about the following aspects was requested: social academic and professional, such as, gender, age, marital status, current semester attending in university, years working as educator, level of education in which they work and school program where they work. All this with the purpose of putting into practice and testing $\mathrm{H}_{\mathrm{i} 2}$.

\section{Results}

In general terms, the obtained results for each the dimensions as well as in global terms are shown in the table 1 .

Table 1. Descriptive results of self-concept

\begin{tabular}{lcc}
\hline Self-concept (dimension) & $\begin{array}{c}\text { Arithmetic } \\
\text { measure }\end{array}$ & Standard deviation \\
\hline Academic & 22.41 & 3.48 \\
Social & 21.24 & 2.49 \\
Emotional & 16.75 & 4.06 \\
Family & 21.67 & 2.91 \\
Physical & 20.56 & 4.23 \\
Global self-concept & 102.62 & 9.36 \\
\hline
\end{tabular}

According toSallum et al. (2011) the scale to interpret the level of global self-concept is: Low 


\section{Al Macrothink}

Journal of Studies in Education

ISSN 2162-6952

2017, Vol. 7, No. 1

30 to 69 points, medium 70 to 109 points, and high 110 to 150 points. Thus, global self-concept of the student-educators reached an average of 102.62 points, which is equal to a medium level. When it comes to dimensional level the highest score was registered in academic self-concept (22.41 points), while the lowest score was emotional self-concept (16.75 points)

In order to determine the normality of the data and thus stablish the adequate statistical test to be implemented, a Kolmogorov-Smirnov test was used, obtained with this the results shown in the table 2.

Table 2. Kolmogorv-Smirnov Normality Test

\begin{tabular}{lcc}
\hline $\begin{array}{l}\text { Self-concept } \\
\text { (dimension) }\end{array}$ & $\begin{array}{c}\text { Kolmogorov-Smirnov } \\
\mathrm{Z}\end{array}$ & $\begin{array}{c}\text { Statistical } \\
\text { significance }\end{array}$ \\
\hline Academic & 1.143 & .147 \\
Social & 1.368 & .047 \\
Emotional & 1.073 & .200 \\
Family & 2.048 & .000 \\
Physical & 1.127 & .158 \\
Global self-concept & .698 & .715 \\
\hline
\end{tabular}

As it is observed in the table above, the academic, emotional, physical and global self-concept dimensions follow a normal distribution, while social and family dimension follow a non-normal distribution. For this reason, parametric test were applied for the first case and nonparametric for the second one.

In respect to the gender (table 3) a significant statistical difference was found only in emotional self-concept. These results represented a higher level in women (17.66 points) than in men (15.52 points); on the other hand, when it comes to marital status (table 3) a significant statistical difference was found only in academic self-concept. In this second case, married student-educators presented a higher score (23.00 points) in comparison to single individuals (21.73 points).

Concerning the educational modality in which the student-educator works (table 3 ), whether in independent or multiple grades organization, physical self-concept was the only one with a significant statistical difference. In this case, those who work in multiple grades class organization shown a higher score (21.27 points) in comparison to those who work in the modality of independent grade organization (19.53 points). 
Table 3. Global self-concept and its dimensions regarding gender, marital status, and educational modality in the workplace

Self-concept average or average range

Academic Social Emotional Family Physical Global

\begin{tabular}{|c|c|c|c|c|c|c|}
\hline $\begin{array}{l}\text { Statistic test } \\
\text { implemented }\end{array}$ & Student* $^{\mathrm{t}}$ & $\begin{array}{c}\text { U } \\
\text { Mann- } \\
\text { Whitney }\end{array}$ & t Student* & $\begin{array}{c}\text { U } \\
\text { Mann- } \\
\text { Whitney }\end{array}$ & $\begin{array}{c}\mathrm{t} \\
\text { Student* }\end{array}$ & $\begin{array}{c}\mathrm{t} \\
\text { Student* }\end{array}$ \\
\hline
\end{tabular}

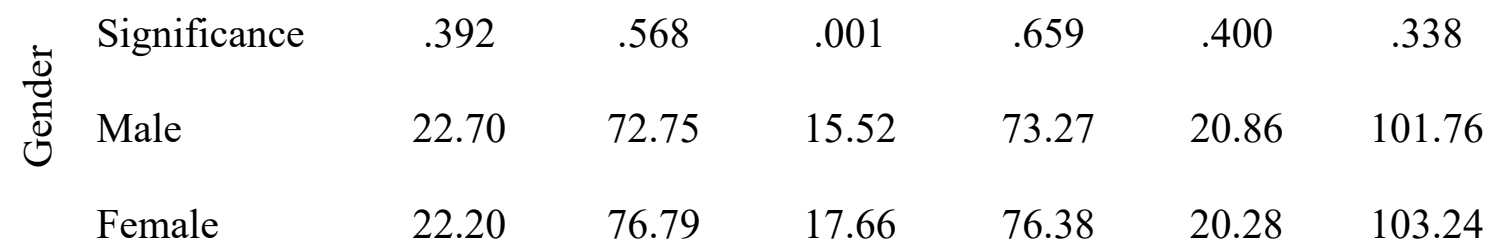

\begin{tabular}{|c|c|c|c|c|c|c|}
\hline Significance & .023 & .082 & .070 & .082 & .852 & .436 \\
\hline Single & 21.73 & 69.10 & 17.36 & 69.09 & 20.53 & 101.91 \\
\hline Married & 23.00 & 81.31 & 16.17 & 81.31 & 20.40 & 103.11 \\
\hline
\end{tabular}

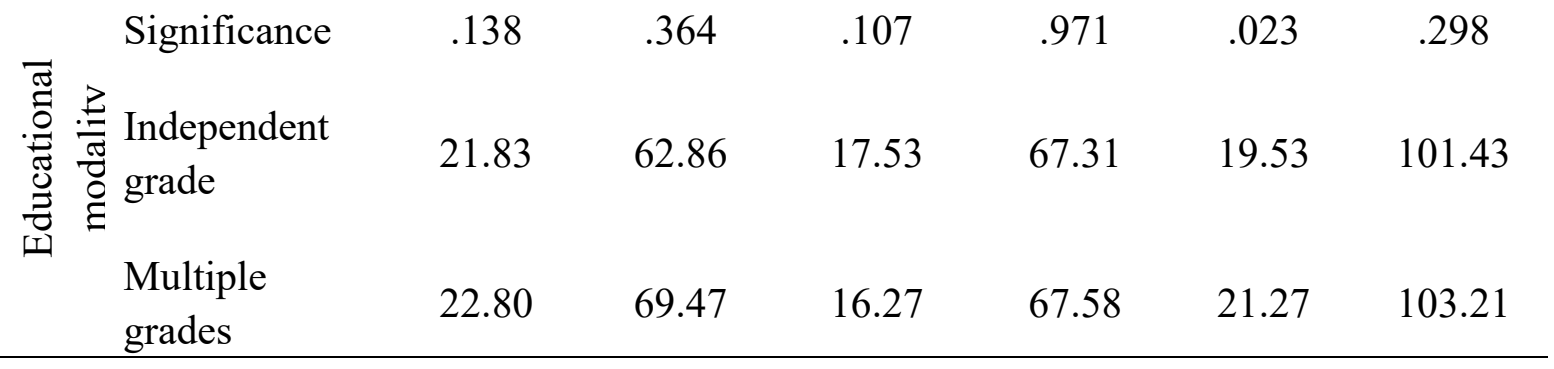

*Assuming equal variances according to the Levene test.

In order to determine whether a correlation between self-concept, age, years working as educator exists or not, a Pearson statistical test or Spearman, depending on each case was used and the results obtained are shown in table 4. 


\section{Macrothink}

Journal of Studies in Education

ISSN 2162-6952

2017, Vol. 7, No. 1

Table 4. Global self-concept and its dimensions regarding age and years working as educator

\begin{tabular}{lccc}
\hline \multicolumn{1}{c}{$\begin{array}{c}\text { Self-concept } \\
\text { (dimension) }\end{array}$} & Test implemented & Level of correlation \\
& Pearson & .008 & $\begin{array}{c}\text { Years working as } \\
\text { educator }\end{array}$ \\
\hline Academic & Spearman & $.182^{*}$ & .023 \\
Social & Pearson & -.036 & .035 \\
Emotional & Spearman & .063 & -.092 \\
Family & Pearson & -.059 & -.164 \\
Physical & Pearson & .001 & -.146 \\
Global self-concept & & & -.124 \\
\hline
\end{tabular}

*Significant correlation to the level 0.05 (bilateral)

It was only possible to find a significant statistical correlation between social self-concept and age of the participants with positive results. It is for this reason that a conclusion is reached in which the older the student is, the higher is their level of self-concept in the person. In regard to the years working as educator it was not possible to determine a significant statistical relation to self-concept.

Finally, in table 5 a significant statistical relation is shown between self-concept and the semester that the participants were attending as well as the level of education in which they work (pre-school, elementary or middle school). 
Table 5. Global self-concept and its dimensions regarding their semester in university and level of education in their workplace

\begin{tabular}{lccc}
\hline $\begin{array}{l}\text { Self-concept } \\
\text { (dimension) }\end{array}$ & $\begin{array}{c}\text { Statistical test } \\
\text { implemented }\end{array}$ & $\begin{array}{c}\text { Semester in } \\
\text { university }\end{array}$ & $\begin{array}{c}\text { Level of } \\
\text { education in } \\
\text { workplace }\end{array}$ \\
\hline Academic & ANOVA & .103 & .041 \\
Social & Aruskal-Wallis H & .084 & .140 \\
Emotional & Kruskal-Wallis H & .143 & .668 \\
Family & ANOVA & .051 & .025 \\
Physical & ANOVA & .087 & .349 \\
Global self-concept & & .005 & .924 \\
\hline
\end{tabular}

As shown in the table above, the semester in university is statistically significant in the global self-concept. In this respect, the lowest level was found in those students from second semester with 98.88 points. On the other hand, the highest level was obtained by those students from first semester with 107.27 points (using Duncan test, table 6).

Table 6. Duncan test for global self-concept in relation to the semester

\begin{tabular}{lcc}
\hline \multicolumn{1}{c}{ Semester } & Average subset 1 & Average subset 2 \\
\hline Second & 98.88 & \\
Sixth & 100.00 & 100.00 \\
Third & 100.53 & 100.53 \\
Fifth & 101.17 & 101.17 \\
Seventh & 101.60 & 101.60 \\
First & & 102.27 \\
\hline
\end{tabular}

The level of education of the participants' workplace demonstrated a significant statistical difference in the academic self-concept and the family self-concept (table 5). For the first case, the students who work in pre-school level showed the lowest soccer (21.54 points), while those who work in the level of middle school obtained the highest score with 23.77 points (using the Duncan test, table 7). 


\section{Ml Macrothink}

Table 7. Duncan test for academic self-concept in relation to the level of education of participants' workplace.

\begin{tabular}{lcc}
\hline \multicolumn{1}{c}{ Level } & Average subset 1 & Average subset 2 \\
\hline Pre-school & 21.54 & \\
Elementary school & 22.55 & 22.55 \\
Middle school & & 23.77 \\
\hline
\end{tabular}

For the second case, the family self-concept was higher in those who work in pre-school level and the lowest was presented in the one who work in middle school (table 8).

Table 8. Average rangein the Kruskal-Wallis test for family self-concept in relation to the level of education of participants' workplace

\begin{tabular}{lc}
\hline \multicolumn{1}{c}{ Level } & Average range \\
\hline Pre-school & 86.89 \\
Elementary school & 69.70 \\
Middle school & 59.21 \\
\hline
\end{tabular}

\section{Discussion and conclusion}

Taken from the analysis of the results, it was possible to conclude that global self-concept in student-educators reached a medium level (matching Martinez 2003 results) and for this reason was not possible to accept the hypothesis of the investigation $\mathrm{H}_{\mathrm{i} 1}$ which was directed towards a lower level in the results. At a dimensional level, academic self-concept registered the highest score, while emotional self-concept the lowest. This does not match the results of Garcia (2005); nevertheless, this non-coincidence may be because of the different results in the tools implemented in the investigation: Questionnaire AF5 and Harter's self-perception scale of profile.

When it comes to the second research question, global self-concept could only be statistically related to the semester in university that the students-educators were attending.

However, at a dimensional level emotional self-concept could be differentiated between men and women, having found that in the results in women did not match the results of Valdez and Gonzalez (1999). Academic self-concept was higher in married student-educators than those who were single, plus, the one who work in middle school presented a higher level in the self-concept previously mentioned. Physical self-concept was statistically higher in those who work in the modality of multiple graders in the groups, in contrast to the ones who work in independent group organization modality. In another self-concept, the one about family, the higher was for those who work in pre-school. This was somehow similar to the figures 
reported by Ibarra, Armena and Jacobo (2014) when differentiating the levels of self-concept in educators in regard to contextual aspects. Additionally, a positive correlation was found between social self-concept and the age of the participants, this means that the older are the students the higher is their level of self-concept.

After discussing the information above, it is possible to accept the hypothesis of the investigation $\mathrm{H}_{\mathrm{i} 2}$ "There are certain social, academic and professional variables which have a relation with the level of self-concept of the student-educators of the LEPEPMI". It is important to clarify that such an acceptance is partially considered due to the fact that only in one of the variables it could be possible to identify the influence (or association) with global self-concept, yet at a dimensional level, several associations were found.

It is recommended to continue investigating self-concept in Mexican scholars from different levels of education and different context; this, with the purpose of starting a configuration of a profile that could provide the basis for intervening in a precise way in vast communities.

\section{References}

Barraza, G., \& Hernandez, L. (2016). Autoconcepto y Rendimiento Académico en Estudiantes de Educación Secundaria. Visión Educativa IUNAES, 10(22), 22-31. Available: http://iunaes.mx/inicio/wp-content/uploads/2016/12/REVISTA-VISI\%C3\%93N-EDUCATIV A-IUNAES-22.pdf

Bartra, A., Guerra, E., \& Carranza, R. (2016). Autoconcepto y Depresión en Estudiantes Universitarios de una Universidad Privada. Revista Apuntes Universitarios, VI(2), 53-68. Available: http://www.redalyc.org/pdf/4676/467647511004.pdf

Garcia, L. (2005). Autoconcepto, Autoestima y su Relación con el Rendimiento Académico. Tesis. México: Universidad Autónoma de Nuevo León. Available: http://eprints.uanl.mx/6882/1/1080127503.pdf

Garcia, F.,\&Musitu, G. (2001). Manual AF-5. Autoconcepto Forma 5. Madrid: TEA ediciones.

Hernandez, L. (2016). Self-concept in Mexican Scholar Children. International Journal of Recent Scientific Research, 7(6), 12140-12144. Available: http://www.recentscientific.com/self-concept-mexican-scholar-children?page $=5$

Hernandez, R., Fernandez, C., \& Baptista, L. (2010). Metodología de la Investigación (quinta ed.). Perú: McGraw Hill.

Ibarra, E., Armenta, M.k., \& Jacobo, H. (2014). Autoconcepto, Estrategias de Afrontamiento y Desempeño Docente Profesional. Estudio Comparativo en Profesores que Trabajan en Contextos Adversos. Profesorado. Revista de currículum y formación del profesorado, 18(1), 223-239. Available: https://recyt.fecyt.es/index.php/profesorado/article/view/41078

Ibarra, E.,\& Jacobo, H. (2016). La Evolución del Autoconcepto Académico en Adolescentes. Revista Mexicana de Investigación Educativa, 21(68), 45-70. Available: http://www.scielo.org.mx/pdf/rmie/v21n68/1405-6666-rmie-21-68-00045.pdf 


\section{Macrothink}

Journal of Studies in Education

ISSN 2162-6952

2017, Vol. 7, No. 1

Kerlinger, F., \& Lee. H. (2002). Investigación del Comportamiento. Métodos de Investigación en Ciencias Sociales (cuarta ed.). México: McGraw-Hill.

Martinez, V. (2003). Autoconcepto Docente: Análisis de una Muestra de Profesores y orientadores Mexicanos. RevistaEducación y Futuro.

Purkey, W. (1970). An Overview of Self-Concept Theory for Counselors. ERIC Clearinghouse on Counseling and Personal Services. Mich: Ann Arbor.

Ramos, E., Rodriguez, A., Fernandez, A., Revuelta, L.,\&Zuzagoitia, A. (2016). Apoyo Social Percibido, Autoconcepto e Implicación Escolar en Estudiantes Adolescentes. Revista de Psicodidáctica, 21(2), 339-356. https://doi.org/10.1387/RevPsicodidact.14848

Revuelta, L., Rodriguez, A., Arzua, U., \& Ramos, E. (2015). Autoconcepto Multidimensional. Medida y relaciones con el rendimiento académico. Revista Internacional de Evaluación y Medición de la Calidad Educativa, 2(1), 12-24.

Sallum, A., Marin, R., \& Reyes, C. (2011). Autoconcepto y Rendimiento Académico en Estudiantes de Escuelas Secundarias Públicas y Privadas de Ciudad Victoria, Tamaulipas, México. Revista Internacional de Ciencias Sociales y Humanidades, SOCIOTAM, XXI(1), 207-229. Available: http://www.redalyc.org/pdf/654/65421407010.pdf

Shavelson, R., Hubner, J., \& Stanton, G. (1976). Self-concept: Validation of Construct Interpretations. Review of Educational Research, 37(2), 407-441.https://doi.org/10.3102/00346543046003407

Valdes, A., Sánchez, P., \& Carlos, E. 2(012). Autoconcepto Social y Ajuste Escolar de Estudiantes de Educación Media con Conductas de Hostigamiento en la Escuela. Educación y Ciencia, 2(5), 85-96. Available: http://educacionyciencia.org/index.php/educacionyciencia/article/viewFile/294/pdf

Valdez, J.,\&Gonzalez, N. (1999). El Autoconcepto en Hombres y Mujeres Mexicanos. Ciencia Ergo Sum, 6(3), 265-269. Available: http://www.redalyc.org/pdf/104/10401606.pdf

Veliz, A.,\& Apodaca, P. (2012). Dimensiones del Autoconcepto en Estudiantes Chilenos: un Estudio Psicométrico. Revista Educativa Hekademos, 11(V), 47-58. Available: http://www.hekademos.com/hekademos/media/articulos/11/05.pdf

\section{Acknowledgement}

Appreciation to Leonel Sierra for having translated this research report into English. 